\title{
Review on Status of Organic Farming
}

Isreal Zewide

Department of Natural Resource Management, College of Agriculture, Mizan-Tepi Unversity and Natural Resource Management, P,O.Box 260, Mizan-Aman, Ethiopia.

Corresponding Author: Isreal Zewide, Department of Natural Resource Management, College of Agriculture, Mizan-Tepi Unversity and Natural Resource Management, P,O.Box 260, Mizan-Aman, Ethiopia.

Received date: July 21, 2021; Accepted date: August 10, 2021; Published date: August 19, 2021

Citation: Isreal Zewide. (2021). Review on Status of Organic Farming. J. Nutrition and Food Processing, 4(6); DOI:10.31579/2637-8914/061

Copyright: (c) 2020 Isreal Zewide, This is an open access article distributed under the Creative Commons Attribution License, which permits unrestricted use, distribution, and reproduction in any medium, provided the original work is properly cited.

\begin{abstract}
Organic agriculture started much more recently in thousands of years ago, Agriculture almost equal share of the farming systems of crop production and characterizes the key issues of Ethiopian economy. The quality of organic resources and their fertilizer equivalence are the main criteria to be judged for effective utilization of the organic resources for soil fertility improvement and promotion of agricultural products both in quantity and quality. Organic agriculture is production system that sustains the health of soils, ecosystems and people. The evaluation of organic matter in soils depends on type and nature of organic source. Organic agriculture in the extent to which African farmers certified yields (more than 50\% higher than local yield averages). The export main products produced are cotton, sesame and coffee, followed by cocoa, dried fruits, frozen fruit/pulp, fresh mainly tropical fruit and spices. Ethiopia is famous as the origin of coffee and is the largest producer in Africa. Forest coffee has the advantage that it originates from an organic and shaded production area - a quality increasingly important for coffee drinkers worldwide coffee cultivation systems, superior quality and organic in nature. Certified-organic farmers will generally require a higher price to compensate for the costs of inspection, certification and the major source of foreign exchange and thus account more than half of the value of total export. Total number of 12 forest coffee cooperatives in remote areas of southwestern Ethiopia were certified according to Fairtrade, organic (EU standard) and Utz Certified standards. The common understanding of agricultural production in all types of organic agriculture is managing the production capacity of an agro-ecosystem. Pesticides and fertilizers are damaging human health and polluting the surrounding environment and thus violating the sustainability of ecosystem.
\end{abstract}

Keywords: pesticides; vermicomst; cattle manure; human health pollution; marketing; organic farming; Ethiopia; fertilizers; coffee trade

\section{Introduction}

Organic agriculture started much more recently in thousands of years ago, when hunter-gatherers settled down and took up farming. As a concept and ideal, organic agriculture began in the early part of the twentieth century, primarily in Europe, but also in the United States [19]. The world populations will inevitably double by the middle of the twenty-first century, that we are soon to enter, that is in the space of just two generations. Agriculture remains the key sector for the economic development for most developing countries [11]. Organic agriculture in the extent to which African farmers certified yields (more than 50\% higher than local yield averages). So, Ethiopia is basically an agricultural and pastoral country. About $85 \%$ population depends on agriculture for their livelihood and also Ethiopia is a land-locked country known as 'Horn of Africa'. Increased soil organic matter (SOM) contents raise resilience against drought, a key challenge for Ethiopian agriculture. Additionally, the adoption of methods might increase productivity among many farmers [10]. Regarding to organic farming of some crops like coffee, cocoa and tea [8]. By looking these environmental problems due to this chemical based farming, the government of Ethiopia issued a new policy guideline on Rural Development in World Summit on Sustainable Development. The process of extreme specialization propagated by the green revolution led to the destruction of mixed and diversified farming and ecological buffer systems. The function of this autonomous ecosystem management is to meet the need for food and fibers on the local ecological carrying capacity [18]. organic farming through meaningful application of different organic resources of both plant and animal origins including farmyard manures, composts, crop residues, bone meals, coffee husk/pulp, other byproducts of agricultural processing plants and their scientific integrations with synthetic and mineral fertilizers on sustainable basis. This has also been emphasized by [24]. 


\section{Objective}

To review the status of organic farming in Ethiopia

\section{Discussion}

\section{Organic Farming}

\section{What is Organic Farming?}

Organic farming is a type of agriculture or farming which avoids the use of synthetic fertilizers, pesticides, growth regulators, and livestock feed additives. It emphasizes the use of management practices in preference to the use of off-farm inputs, taking into account that regional conditions require locally adapted systems (Reddy, 2010). You can always taste the difference between organically grown and conventionally grown products (wordpress.com 2014). Building up organic matter requires precipitation/irrigation, because biomass is only built up when it rains [1, 13]. The dual advantage being the positive effects on the environment on one hand as well as to make the farmer self-sufficient as far as his requirements regarding agro- inputs are concerned and that too at a reduced price [2]. Productivity and profitability of organic agriculture in East Africa finds in 2010/11 approximately 330,000 certified organic producers in Uganda and Tanzania alone generated approximately USD 56 million in export revenue. The main products produced are cotton, sesame and coffee, followed by cocoa, dried fruits, frozen fruit/pulp, fresh mainly tropical fruit and spices [16]. Certified organic production is largely an institutional arrangement in which exporters organize. Small holders to produce and process certified organic produce for export to well established organic markets. However, significant proportions of the certified organic produce are sold locally on conventional markets due to specification issues (e.g. size requirements) and farmers needing cash flow [7].

\section{Organic resources and soil fertility Source}

As a quick chemical assessment of soil fertility status in most of Ethiopian soils is in relation to organic matter and total nitrogen. The evaluation of organic matter in soils depends on type and nature of organic source, ease of decomposition and overall soil and climatic environment [2,12]. The soils of the highlands in most part of Ethiopia contain considerable amounts of organic carbon content particularly in the surface layers under sub-humid climate. Most of the clay mineral suites indicate smectite or its interstratifications as the dominant minerals particularly. The rate of decomposition and net mineralization of soil organic matter depends on the accessibility of organic substrates to soil microorganisms [12]. Organic agriculture is defined by [7] as: a production system that sustains the health of soils, ecosystems and people. Certified-organic farmers will generally require a higher price to compensate for the costs of inspection and certification.

Yet, often producers can only sell part of their organic crops at a premium price, whereas rotational crops may not be able to obtain a price premium at all [16]. Soils managed with organic methods have shown better water holding capacity and water infiltration rates and have produced higher yields than conventional systems under drought conditions and excessive rainfall [22].

\section{Challenges of organic farming}

The challenges and constraints identified for the adoption of methods in Ethiopia need to be analyzed with a systemic perspective. With the commitment of state actors many of the elaborated challenges \& constraints might be properly addressed and reversed. Strong support of research institutions, capacity building among extension services as well as farmers, farmer field schools and demonstration farms may be pathbreaking to establish organic farming practices [10]. competitiveness is important because export of coffee is the major source of foreign exchange and thus account more than half of the value of total export.
Regarding from the coffee market, International competitiveness in market of coffee commodity exports has a major challenges for Ethiopia [14].

\section{Coffee production in Ethiopia}

Ethiopia is the origin of worldwide Arabica coffee. It is the second most traded commodity in the world market after petroleum (Girma, 2011). An estimated $30 \%$ of Ethiopia's coffee production originates from forest. Forest coffee has the advantage that it originates from an organic and shaded production are a quality increasingly important for coffee drinkers worldwide [23].coffee cultivation systems, superior quality and organic in nature, indicating the huge potential of fetching high price premium in both domestic and the international markets (FAOSTAT, 2011). The production is estimated at around 141.9 million bags in crop year 2014/15, while an initial estimate of world coffee consumption in year 2014 comes to 149.3 million bags, this suggests about the existence of resilient demand for coffee worldwide (ICO, 2015). Coffee (Coffea L.) is the world's favorite and non-alcoholic beverage and the second-most traded commodity after oil. Arabica coffee (Coffea arabica L.) and Robusta coffee (C. canephora Pierre ex A. Froehner) are the two main species used in the production of coffee (Davis et al., 2012). The coffee unions contact ECX grading systems and to follow the rules and regulation of the government of Ethiopia [10].

\subsection{Status of Coffee Production in Ethiopia}

Ethiopia is famous as the origin of coffee and is the largest producer in Africa. In production of Arabica coffee, Ethiopia is the sixth largest producer in the world. About 15 million people (almost 20 percent of the total population) directly or indirectly depend on coffee for their living (USDA, 2012, a cited by NASIR, 2016) [15]. The total land area of about $5,68,740(3.91 \%)$ hectares are covered by coffee, from which a total volume of about 4,199,801.56 quintals of coffee are obtained, from $4,723,483$ private peasant holdings in the agricultural year (CSA, 2014/2015, a cited by NASIR, 2016) [15]. Currently, Ethiopia exports 170,000 tons and has a domestic consumption is estimated to be about $50 \%$ of the total production (Aklilu and Ludi, 2010, a cited by, NASIR, 2016) [15]. Although coffee is produced in many parts of Ethiopia most of the marketed coffee comes from the regions of Oromia and Southern Regional State. The two regions contribute for about $99 \%$ of the total coffee production (64\% from Oromia, 35\% from SNNP) and the remaining 1\% comes from Gambela Regional State (FDRE-MOT, 2012, a cited by , NASIR, 2016) [15].

\subsection{Theory of Marketing Channel}

The term marketing channel was first used to describe the existence of a trade channel bridging producers and users. This description makes it easy to understand how the term 'middleman' came into being as a way to explain product flows. Since then, a whole lot of other flows have been made possible by marketing channels [14]. The discouraged coffee market value result in polices regulating the market, and the low base of market infrastructure, lack of adequate marketing information system, high seasonal price variability, and the unorganized sector, high transaction cost, and mainly the longer marketing channel. In the first place, this traditional market comprises large number of small holder coffee farmers. Also, they are illiterate, poorly connected to one another and with market systems [4]. The Ethiopian coffee importing countries are first German coffee importer, Japan, the Netherlands, and America. These foreign importers after adding some value to the coffee they received, they directly sell to wholesalers and then to supermarkets (MOT, 2012). In Sheko and South Bench Woredas the four largest coffee collectors handled about $68.8 \%$ and $60.33 \%$ of the total volume purchased, respectively. According to Kohls and Uhl (1985, a cited by Gachena and Solomon, 2014) [4]. The coffee market in both woredas is a strongly oligopolistic market. This indicates that there is a market 
imperfection because few traders seem to have monopolized the coffee market. The wholesalers are also strongly oligopolistic in both Woreds although the concentration ratio is more pronounced in South Bench woreda where the number of wholesalers is small [4].The market operation on Ethiopia coffee trade, even though coffee has economic and social importance for the Ethiopian economy, the market operation on the coffee sector has remained unsatisfactory especially for smallholders coffee growers. This is because there is no significant change in the form of production and processing for several decades. Regarding from the coffee market, International competitiveness in market of coffee commodity exports has a major challenges for Ethiopia, competitiveness is important because export of coffee is the major source of foreign exchange and thus account more than half of the value of total export [14].

\subsection{Factors Affecting Market Supply}

Agricultural markets in Ethiopia before 2008 had been characterized by high costs and risks of transacting and little access to market information due to a long-chain supply of coffee with several market intermediaries $[3,25]$. Aklilu and Ludi (2012) indicated that even though the government deals with coffee marketing, the country has been constrained by poor marketing performance of agricultural products in general and coffee sub-sector in particular. Factors affecting market supply of coffee was done by using the multiple linear regression model. For instance, Wendmagegn (2014) identified that the major factors that affect market supply of coffee by using multiple linear regression analysis in dale district of SNNPRS [27]. used multiple linear regressions to identify Analysis of marketed surplus of coffee by smallholder farmers in Jimma zone, Ethiopia. The result of OLS regression showed that: sex, coffee farming experience, access to credit, adequacy of extension services, attractiveness of coffee price, cooperative membership and non and/or off farm income are significant positive factors affecting marketed surplus of coffee [1]. Coffee value chain analysis in Meta district, East Hararghe zone of Oromia, Ethiopia. Using multiple linear regression he identified that years of farming experience, extension contact, market information and land holding are positively affect market supply of coffee positively in the district [1]. Addisu (2016) also employed two-stage least square regression model to identify factors affecting the volume of potato and onion supplied to the market due to the presence of potential endogenous which is productivity. Therefore, the potential endogenous variable (quantity of coffee produced) was instrumented by land allocated under coffee and years of farming experience.

\subsection{Certified Coffee}

The certification of coffee started in Ethiopia in the late 1990s with the certification of agricultural producer cooperatives by Addis Ababa based branches of European certification agencies. The first forest coffee producing cooperative was certified in 2002. In May 2007, a total number of 12 forest coffee cooperatives in remote areas of southwestern Ethiopia were certified according to Fairtrade, organic (EU standard) and Utz Certified standards [23]. Coffee forest areas of southwestern Ethiopia (Bench Maji and Kaffa Zone) forest coffee certification activities do not adequately promote conservation of the coffee forest ecosystem and its biodiversity. This is mainly due to the fact that certification standards are principally designed to target agricultural coffee production systems and do not adequately consider the specific ecological and socioeconomic circumstances of Ethiopian forest coffee. Certification fees of several thousands of US dollars per year are covered for the most part by donorfinanced development and trade promotion programs, raising questions of the financial sustainability of certification initiatives [23]. Local governments can help them by improving their organizational and business capacities. Concomitantly, external actors (international traders in particular) need to better understand the local conditions under which products are produced and certified. This combination would allow more sustainable, tailor-made certification and more equal partnerships [28].

\subsection{The Future for Organic Agriculture}

Organic agriculture is the better option for development because of the principles underlying it [26]. Issues such as right-based approaches, land tenure issues, land grabbing, women's empowerment, land degradation, resilience, participatory food system governance, perverse subsidies and unfair trade policies, protection of ecosystem functions, nutrition, ruralurban linkages, food waste, deforestation, diversity and adoption of climate smart agriculture practices (largely based on existing organic practices) are now increasingly seen as part of the holistic approach needed to effectively nourish an estimated 9billion people by 2050 while simultaneously eradicating extreme poverty [7].

\section{Conclusion}

Organic farming has been recognized worldwide for personal health, safe environment, food security and fight against global warming. Agriculture remains the key sector for the economic development for most developing countries and Organic farming perceptions are quite divergent. But there is a strong consensus on its eco-friendly nature and inherent ability to protect human health. Also, many studies have revealed that organic agriculture is productive and sustainable. Organic food production costs are higher in the developed countries as organic farming is labor intensive and labor is costly in these countries. Even different organizations have been set up for the marketing of the produce of organic farming. The increasing demand for the organic food products in the developed countries as well as the policies adopted by the government to encourage the exports of the organic agro-products are the driving factors responsible for the uprising of the organic food industries. pesticides and fertilizers are damaging human health and polluting the surrounding environment and thus violating the sustainability of ecosystem. Ethiopia is famous as the origin of coffee and is the largest producer in Africa. In production of Arabica coffee, Ethiopia is the sixth largest producer in the world. About 15 million people (almost 20 percent of the total population) directly or indirectly depend on coffee for their living. Forest coffee has the advantage that it originates from an organic and shaded productions are a quality increasingly important for coffee drinkers worldwide. The market operation on Ethiopia coffee trade, even though coffee has economic and social importance for the Ethiopian economy. Local governments are mostly concerned with agricultural initiatives that aim to increase quantities and quality of agricultural products. Beyond this, they should actively promote more integrated and bottom-up approaches of certification, and take a leading role as mediator between local and external actors and interests. Certification standards are principally designed to target agricultural coffee production systems and do not adequately consider the specific ecological and socioeconomic circumstances of Ethiopian forest coffee. The common understanding of agricultural production in all types of organic agriculture is managing the production capacity of an agroecosystem.

\section{References}

1. Bizualem, A., Degye, G., Zekarias, S., (2015). Analysis of marketed surplus of coffee by smallholder farmers in Jimma zone, Ethiopia. Journal of Biology, Jemal Dessalegn, CH-6; 253-269.

2. Mamgain, A., (2019). Status, importance, prospects, and vision of organic farming in India. International Journal of Advance Research. 2019.

3. ECX, 2011. ECX (Ethiopian Commodity Exchange). 2009. Market Date. Retrieved Set 16, 2014. 15-18. 
4. Gachena, D., Solomon, K., (2014). Evaluating Coffee Market Structure and Conduct in Bench - Maji Zone, South West Ethiopia.

5. Hashim. (2013). Coffee value chain analysis: The case of Meta District, East Hararghe Zone of Oromia Regional State, Ethiopia. MSc Thesis, Haramaya University, Haramaya Ethiopia.Agriculture and Healthcare, 5(5), 2224-3208.

6. Haslberger A., (2010); Genetically Modified, Organic Crops in Developing Countries, Review of options for food security and Biotechnology Adv 28:160-168.

7. IFOAM, (2013). Productivity and Profitability of organic farming System in east Africa.

8. IFOAM, 2014. The Potential Contribution of Organic Agriculture to the Realization of the Objectives of the Comprehensive Africa Agriculture Development Programme (CAADP) - A Guide for Stakeholder.

9. IFOAM, (2010), International \&Federation Of /Organic! Agriculture -Movements $4^{\text {th }}$ Principles Organic Agriculture.

10. IPES-Food, (2016), from uniformity to diversity: a paradigm shift from industrial agriculture to diversified agro ecological systems. International Panel of Experts on Sustainable Food systems.

11. Kambaskam.K et.al, (2011) Organic Farming History and Techniques.

12. Kibebew, K.T., Mishra, B.B., (2017). Relevance of Organic Farming in Ethiopian Agriculture: Mission and Commitment with Second Green Revolution.

13. Mehmood Hassan, (2017). Organic Agriculture.

14. Mintwn, B., Tamiru, S., Kuma, T., Nyarko, Y., (2014). Structure \& Performance of Ethiopia's Coffee Export Sector, Ethiopian Development Research Institute.

15. Nasir, A., (2016). Value Chain Analysis of Coffee: The Case of Smallholders In Seka Chokorsa District, Jimma Zone, MSc THESIS , Ethiopia Haramaya University, Till Stellmacher,
16. Peter, T., (2013). Productivity and Profitability of Organic Farming Systems in East Africa.

17. Ram, R.A., Pathak, R.K., (2008). Integration of Organic Farming Practices for Sustainable Production of Guava: a case study. Accessed 24 Mar 2008.

18. Smukler S.M., Sanchez-Moreno, S., Ponted, S.J., Ferris, H., Klonsky, K., Ogreen, A.T., Scowb, K.M., Steenwerthg, K.l., Jackson, L.E., (2010). Biodiversity and multiple ecosystem functions in organic farm scape. Agriculture, Ecosystems \& Environment 139, 80-97.

19. Ulrike, G., Jorg, V., (2010). Protection of biodiversity through coffee certification? The case of forest coffee in Bench Maji and Kaffa Zone, Ethiopia.

20. USAID, (2010). Ethiopian Coffee Industry Value Chain Analysis Profiling the Actors, Their Interactions Costs Constraints and Opportunities. Chemonics International Indian Journal of Fertilizers 107, 161-176.

21. Tadese, G., (2015). Determinants of Coffee Export Performance in Ethiopia. Journal of Economics and Sustainable Development. Axum, Ethiopia, Vol.6, No.5, 2015.

22. Seufert, V., N. Ramankutty \& J.A. Foley (2012). Comparing the yields of organic and conventional agriculture. In: Nature, No.485 (10 May 2012), pp.229-234.

23. Stellmacher, T., Ulrike, G., Jorg, V., (2010). Protection of biodiversity through coffee certification? The case of forest coffee in Bench Maji and Kaffa Zone, Ethiopia.

24. Wakene, N., Heluf, G., Abdena, D., Geremew, E., (2014). Integrated use of farmyard manure, and $\mathrm{N}$ and $\mathrm{P}$ fertilizers for maize production under farmers conditions in Western Oromia. Indian Journal of Fertilizers 106(2), 131-141.

25. Webpage: http://www.ecx.com.et/Operations.aspx\#MD.

26. http://www.ifoam.org/aboutifoam/principles/index.

27. http:// www.negahistory wordpress.com 2014/03/20

28. https://www.researchgate.net/publication/226271466

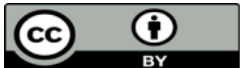

This work is licensed under Creative Commons Attribution 4.0 License

To Submit Your Article Click Here: Submit Manuscript

DOI: $10.31579 / 2637-8914 / 061$

\author{
Ready to submit your research? Choose Auctores and benefit from: \\ $>$ fast, convenient online submission \\ $>$ rigorous peer review by experienced research in your field \\ $>$ rapid publication on acceptance \\ $>$ authors retain copyrights \\ $>$ unique DOI for all articles \\ $>$ immediate, unrestricted online access
}

At Auctores, research is always in progress.

Learn more auctoresonline.org/journals/nutrition-and-food-processing 